\title{
Hong kong working class and union organization: A historical glimpse
}

Sek Hong $\mathrm{Ng}$ et Olivia Ip

\section{OpenEdition}

\section{Journals}

Édition électronique

URL : http://journals.openedition.org/chinaperspectives/1733

DOI : 10.4000/chinaperspectives. 1733

ISSN : 1996-4617

Éditeur

Centre d'étude français sur la Chine contemporaine

\section{Édition imprimée}

Date de publication : 15 avril 2007

ISSN : 2070-3449

Référence électronique

Sek Hong Ng et Olivia Ip, « Hong kong working class and union organization: A historical glimpse », China Perspectives [En ligne], 2007/2 | 2007, mis en ligne le 08 avril 2008, consulté le 28 octobre 2019 URL : http://journals.openedition.org/chinaperspectives/1733; DOI : 10.4000/chinaperspectives.1733 
U

\title{
Hong Kong Working Class
}

\section{and Union Organisation:}

\author{
A Historical Glimpse
}

NG SEK HONG AND OLIVIA IP

This paper attempts to sketch a longitudinal profile on the evolution of a working class in Hong Kong context in light of the thesis of embourgeoisement. The increasing economic affluence in the 1980 s and early 1990 s appeared to have bred an optimism in society that the members of the working class were converging in life-style and consumption behaviour with the middle class in a process of embourgeoisement. However, the thesis of embourgeoisement comes under question again around the turn of the millennium in the advent of globalisation and the successive waves of recession that afflict Hong Kong. The vicissitudes of capitalistic competition, leading to business restructuring, corporate down-sizing and other austerity prescriptions of labour cost-saving, popularise the practices of flexi-hiring, atypical employment, outsourcing, labour shedding and retrenchment. The upshot of these austerity exercises has been the re-casualisation of the labour market and the emasculation of the employment and income security of a growing fringe of peripheral workers vulnerable to industrial deprivation and exploitation. As a consequence we now see a new industrial proletariat or urban sub-class emerging in post-industrial Hong Kong. Its "embrace" as a hybrid working class transcends a spectrum of blue-collar and service occupations. Because of the diversity in its composition, the prospects for a solidaristic working class to emerge are again remote. And the role of the trade unions in providing an effective leverage for uplifting and protecting their position is limited, as illustrated by the "impasse" now still looming over the proposed enactments to prescribe a minimum wage level and standard work hours.

$\mathrm{T}$ The treatment of "class" as a notion has always been diverse and controversial. And a consensus on its definition has been up to now still lacking in the literature. The Marxian approach has emphasised economic position and power as the criteria for distinguishing the working class (proletariat) from the capitalist middle-class (bourgeoisie), while the Weberian perspective has paired the dual notions of "class" and "status groups" as the basis for social stratification of people in society. By the Weberian tradition, it is argued that "classes exist to the extent that the groups share a common market condition as the decisive basis for their specific life chances ${ }^{(1)}$ ". Following such an economic line of exposition about class, class may be conceptualised as a proxy for similarity in the position within the occupational system, especially in the context of modern industrial (post-industrial) society ${ }^{(2)}$. As pointed out by Kocka, an economic class exists where individuals share, due to a common economic position, latent interests ${ }^{(3)}$. In a more explicit language, the class hierarchy is perceived to help "differentiate positions within labour markets and production units or more specifically, to differenti- ate such positions in terms of the employment relations that they entail ${ }^{(4)}$."

The market situation pertains to life chances as they stem from the individual's occupation, having consequences for consumption level, household standard, children's education and other aspects of quality of life. Concomitantly, the working situation elucidates on how production is organised and the location within the authority structure and the degree of autonomy in performing work tasks ${ }^{(5)}$.

In light of the above conceptualisation of class, this article aims to sketch a longitudinal profile on the evolution of a

1. Weber, Max, Wirtschaft and Gesellschaft, Koln under Berlin: Kiepenheuer and Witsch, 1964, pp. 679-80.

2. Oesch, Daniel, Redrawing the Class Map: Stratification and Institutions in Britain, Germany, Sweden and Switzerland, Houndmills, Palgrave Macmillan, 2006.

3. Kocka, J., "The Study of Social Mobility and the Formation of the Working Class in the 19th Century", Le Mouvement Social, $n^{\circ} 111,1980$, pp. 97-118.

4. Erikson, R. and Goldthorpe, J. H., The Constant Flux, Oxford, Oxford University Press, Clarendon paperbacks, 1993.

5. Erikson, R., "Social Class of Men, Women and Families", Sociology, vol. 18, n 4, 1984, pp. 500-14. Also Oesch, Daniel, Redrawing the Class Map: Stratification and Institutions in Britain, Germany, Sweden and Switzerland, Houndmills, Palgrave Macmillan, 2006. 
working class in the Hong Kong context. The paper is structured in the following manner. In the first section, the theoretical underpinnings are presented. In the second section, an attempt is made to elucidate the embourgeoisement of the working class in a few decades of industrialisation after the Second World War. This is followed by a section on the increasingly diversified and deprived working class in the post-industrial society of Hong Kong. Finally, we present discussions and conclusions.

\section{The working class: a changing composition}

It has been commonplace to equate the manual blue-collar workers in the lower tiers of the occupational hierarchy in society with the working class. Such a treatment corresponds to the class "divide" between production workers, agricultural workers in primary production, semi-and unskilled manual workers in industry, skilled manual workers plus lowergrade technicians and supervisors of manual workers on one hand and service workers, higher grade technicians, professionals, administrators, officials and managers on the other ${ }^{(6)}$. In short, the manual versus non-manual, or blue-collar versus, white-collar dichotomy has often been invoked for identifying the former as members of the "working class." Specifically, the working class is viewed to be composed of those who supply labour, vis-à-vis those who provide service ${ }^{(7)}$. As exemplified by Goldthorpe:

A labour contract entails a relatively short-term and specific exchange of money for efforts. Employees supply more or less discrete amounts of labour, under the supervision of the employer or the employer's agent, in return for wages that are calculated on a "piece" or "time" basis. In contrast, a service relationship entails a longer-term and more diffuse exchange in which employees render service to their employing organisation in return for compensation that takes the form not only of reward for work done, through a salary and various perquisites, but also comprises important prospective elements ${ }^{(8)}$.

However, in spite of the mainstream position of the bluecollar manual workers as the vanguard of the working class, it is evident that as industrial societies move into post-industrial late urbanism, the growing pervasiveness of the tertiary service industries accompanied by the attrition of the manufacturing sector has compounded the composition of the working class, which has become increasingly diversified and pluralistic. As lamented by Meikins, "the rise of global capitalism, increasing capital mobility, the shift towards 'flexible' production, technological change, and a series of other developments have transformed occupational structure and stimulated the developments of a variety of 'new' employment relationships ${ }^{(9)}$." The Marxian perspective hence considers as problematic as well the once orthodox definition of proletariat by limiting its scope to the "manual industrial workers only in the pattern of nineteenth century." Such a definition needs widening in order to be realistic and compatible with "the present situation when manual workers in traditional industry are sharply declining giving place to service workers and commercial workers including part-time and casual workers ${ }^{(10)}$." Because of the sectoral re-distribution of employment to the tertiary from the secondary sector in post-industrial societies, service workers of lower status and lesser skills proliferate and are located within the lower strata of the occupational structure. Examples are the sales workers, restaurant and catering workers, transport workers, security guards and even clerks whose jobs have become increasingly routine and de-skilled. Parallel to the syndrome of shifts in the occupational structure has been the re-casualisation of the labour market leading to the proliferation of various flexi hiring practices and a drift towards and expansion of atypical employment as in the form of part-time employment, temporary and shortterm contract hiring, contingent worker arrangement, outsourcing to external agencies and subcontractors. These workers on non-standard (non-regular) employment are peripheral and typically low paid, lacking in job security-always on the move but basically trapped in the secondary sector of the labour market ${ }^{(I I)}$. Adding to this pool of the industrially marginal and deprived is a hybrid mix of foreign guest workers, seasonal and migrant labour, as well as females and recent migrants (i.e. the ethnic minority) entering the employment market.

6. Erikson, R. and Goldthorpe, J. H., The Constant Flux, Oxford, Oxford University Press, Clarendon paperbacks, 1993. Also cited in Oesch, Daniel, Redrawing the Class Map: Stratification and Institutions in Britain, Germany, Sweden and Switzerland, Houndmills, Palgrave Macmillan, 2006

7. Erikson, R. and Goldthorpe, J. H., ibid...

8. Goldthorpe, J. H., "The 'Goldthorpe' Class Schena: Some Observations on Conceptual and Operational Issues in Relation to the ESRC Review of Governmental Social Stratifications", in D. Rose and K. O'Reilly (eds.), Constructing Class: Towards a New Social Classification for the U.K., London, Office for National Statistics, 1997, pp. 40-8.

9. Meikins, Peter, "'Same As It Ever Was'? The Structure of The Working Class”, in Ellen Meikins, Peter Meikins and Michael Yates (eds.), Rising From the Ashes? Labor in the Ages of "Global" Capitalism, New York, Monthly Review Press, 1998, pp. 28-40.

10. Sen, Sukomal, "Communist Manifesto and the Modern Working Class: What Revolutionary Potentials?" The Marxist, vol. 14, n 4, October-December, 1998, pp. 1-20.

11. Meikins, Peter, op.cit., pp. 28-40. 
$\pi$

$\geq$ Evidently, such a complex constellation of workers of low skill, status and pay stemming from the segmentation of the labour force in post-industrial societies into "a permanent core and a temporary periphery ${ }^{(12) " ~ h a s ~ t o ~ b e ~ r e c k o n e d ~ a s ~}$ members constituting the modern working class. In this connection, the new paradigm of work and employment in postindustrial societies warrants the revised interpretation of the working class boundaries and composition to mirror its present diversity and pluralistic nature, as the Marxian writers concede:

Considering all these facts and formulations, today's manufacturing worker, skilled service sector workers, commercial workers in the mercantile firms and financial institutions like banks, insurances and the clerical and subordinate workers in the service to the capitalists in the phenomenally expanded government sectors, the scattered and individual daily workers - all naturally come within the definition of the wage-workers while the industrial wage-workers form the core of the proletarian class ${ }^{(13)}$.

\section{The affluent worker and embourgeoisement?}

In spite of the heydays of the Hong Kong-Chinese labour movement sustained by a solidaristic working class in the 1920s as manifested in the nostalgic episodes of industrial strife and labour agitation (notably, the Seamen Strike of 1922 and the Hong Kong-Canton General Strike and Boycott of 1925-26), it is argued that a home-grown class structure and a working class have not crystallised in post-war Hong Kong because of its transient nature as a migrant society swamped by a refugee population seeking asylum from the mainland politico-social upheavals. Industrialisation which commenced in the 1950s would have been conducive to the gestation of a refractory working class consciousness among the factory workers labouring under "sweat shop" conditions; but such a propensity was nullified by the pervasiveness of the refugee mentality-so that the labour unions also became industrially docile.

As Hong Kong's industrial economy advanced into a higher realm of sophistication in the 1980s, the Hong Kong worker has also become more economically affluent. During the compressed period of a few decades of industrialisation Hong Kong had sustained an almost uninterrupted process of continuous economic growth which became especially conspicuous in the 1980s. For instance, the average annual growth rate during the ten-year period between 1981 and 1991 registers a level of 4.5\% a year. And Hong Kong
Table 1. Movement in the real wage index in the manufacturing industry

(June $1980=100)$

\begin{tabular}{l|ll}
\hline Year & \multicolumn{1}{|l}{ Index } \\
\hline 1982 & 113.1 & \\
\hline 1983 & 116.3 & \\
\hline 1984 & 123.0 & \\
\hline 1985 & 133.6 & \\
\hline 1986 & 147.2 & \\
\hline 1987 & 148.8 & \\
\hline 1988 & 161.4 & \\
\hline 1989 & 170.0 & \\
\hline 1990 & 167.3 & \\
\hline 1991 & 173.1 & \\
\hline 1992 & 196.9 & \\
\hline
\end{tabular}

Sources: Census and Statistics Department, Hong Kong Government, Annual Digest of Statistics, various years cited from Edward Chen, "The Economic Setting", in Ng Sek Hong and David G. Lethbridge (eds.), The Business Environment in Hong Kong, 3rd edition with a post-handover postscript on the Hong Kong SAR, Hong Kong, Oxford University Press, 1998, Table 1.1 (a), p. 17.

emerged as one of the more successful newly industrialised economies (NIE) in East Asia. Gross domestic product (GDP) rose by $5.5 \%$ in 1993. If adopting March 1982 as the base period for measurement, the territory's nominal wage index advanced from 120.4 in 1984, to 136 in 1986, 210 in 1990, and 233 in 1991; while the real wage index was correspondingly 87.2 in 1984, 104 in 1986, 115 in 1990 , and 114 in $1990^{(14)}$. Industrial wages level also escalated in the manufacturing sector, yet at a pace slower than in the service sector-possibly due to a more acute labour shortage in the latter. Table 1 indicates the ascending trend of the manufacturing real wage during the 1980s and table la presents a comparative profile of real wage movement across the major sectors of the economy between the late 1980s and beginning of the 1990s.

\section{Ibid., p. 32}

13. Sen, Sukomal, op.cit.

14. Census and Statistics Department, Hong Kong Government, Hong Kong in Figures, Hong Kong: Census and Statistics Department, 1985 edition and 1992 edition. 
Table 1a. Movements of wage indices by selected economic sector (September 1987 to September 1991)

\begin{tabular}{l|c|c}
\hline Economic Sector & $\begin{array}{c}\text { Nominal wage } \\
\text { index } \\
\% \text { change }\end{array}$ & $\begin{array}{c}\text { Real wage } \\
\text { index } \\
\% \text { change }\end{array}$ \\
\hline Manufacturing & 51 & 3 \\
\hline Transport services & 69 & 15 \\
\hline Business services & 80 & 23 \\
\hline Personal services & 75 & 20 \\
\hline $\begin{array}{l}\text { Wholesale, retails, } \\
\text { import/ export trades, } \\
\text { restaurants and hotels }\end{array}$ & 57 & 7 \\
\hline
\end{tabular}

Note: Base year for wage index: March 1982; wage index covers both manual and non-manual workers, but excludes professional and managerial workers

Source: Labour Department, Hong Kong Government, Labour and Employment in Hong Kong, Hong Kong: cyclostyled, July 1992, Figure 9, p. 12. Cited in David G. Lethbridge and Ng Sek Hong "Labour and Employment", in Ng Sek Hong and David G. Lethbridge (eds.), The Business Environment in Hong Kong, 3rd edition with a post-handover postscript on the Hong Kong SAR, Table 3.5, p. 74.

Concomitantly, since the 1980s there has been a slow yet steady narrowing of the income differentials between the white-collar workers. As illustrated by Turner and his associates from their study, such differentials have declined from nearly two-thirds in 1976 to less than one-fifth in $1985^{(15)}$. However, the Gini coefficient has been staggering on an upward trend, increasing from 0.43 in the mid 1970 s to 0.46 by the mid $1980^{(16)}$. The trend was literally reversed in 1986 when the coefficient dropped to 0.455 . Yet, in the early 1990s it resumed its rising trend again and ascended to $0.48^{(17)}$. Such a movement suggests persisting and even worsening equality in the distribution of income among people in society.

Although Hong Kong continued to pale as a place of uneven income and wealth distribution, there were visible improvements in the materialistic provisions and standard of living (and by extension, quality of working life) among members in the industrial working class during the 1980s and early 1990s because of the uplift in their wage and earning levels-attributable probably to not only their intrinsic productivity advances (made possible by their skill betterment and capital investment in plant and machinery) ${ }^{(18)}$ but also a creeping drift towards scarcity of supply in the labour mar- ket. The maturing demographic structure of Hong Kong society has implied a slow-down in the natural growth of the domestic population. This factor, together with the strenuous control upon illegal immigrants at the border by both the Chinese and Hong Kong authorities, has made the internal growth of the labour force relatively stagnant and incommensurate with the strong manpower demand in industry emanating from a buoyant economy, especially in the export, and later, the tertiary service sectors. The entire labour shortage syndrome hence worked to push up wage levels as employers' mutual bidding for skills and manpower intensified. It also caused the economy to re-structure in an attrition process of de-industrialisation inasmuch as it induced Hong Kong's manufacturing plants to re-locate across the border northwards in lower cost areas in southern China.

Besides the wage nexus, there were also other factors contributing to the growing economic affluence of the Hong Kong workers. First, the "social wages" provided by the government, as in the form of public housing, free or inexpensive medical care and hospital services and availability of universal education for at least ten years and expanded tertiary level education which helped enhance the life chances (especially for upward inter-generational mobility) of children for working class parents-alongside the consistent and cheap supply of raw food and light consumer goods from mainland China-became a sizable or even a major subsidy to their take-home income and earnings. Second, there was an evident phenomenon of convergence in life-style and consumption behaviour of blue-collar workers and their families with their white-collar counterparts. In particular, the China Product Emporium Stores excelled around this period in selling inexpensive necessities and consumer goods to the grassroots labouring masses ${ }^{(19)}$. These stores established large branches in densely populated districts "to give easy access to people from the grassroots level; they also serve... as de facto collecting points for working class shoppers to purchase in bulk low-cost merchandise to be taken back to

15. Turner, H. A., Fosh, Patricia and Ng, Sek Hong, Between Two Societies: Hong Kong Labour in Transition, Hong Kong, Centre of Asian Studies, University of Hong Kong, 1991.

16. Ibid., p. 17.

17. See Lethbridge David G. and Ng, Sek Hong, "Labour and Employment”, in Ng Sek Hong and David G. Lethbridge (eds.), The Business Environment in Hong Kong, 3rd edition with a post-handover postscript on the Hong Kong SAR, Hong Kong, Oxford University Press, 1998, pp. 64-88. This was stated by the Secretary for Economic Services (Hong Kong Government), Mrs Anson Chan, in 1992 before the Legislative Council. See report in the South China Morning Post, 27 February 1992.

18. Lethbridge David G. and $\mathrm{Ng}$, Sek Hong, op.cit.

19. Ng Sek Hong and Poon, Carolyn Y. W., Business Restructuring in Hong Kong: Strengths and Limits of Post-Industrial Capitalism, Hong Kong, Oxford University Press, 2004. 


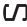

their Mainland relatives ${ }^{(20)}$." Hence, improvements in wage conditions at the grass-roots level made it possible for the labouring masses to assume a more consumption-oriented lifestyle, in place of the austerity ethos which pervaded their poverty-ridden refugee psychology in the fifties and sixties. ${ }^{(21)}$ Given their elevation in economic affluence, they also began to patronise the department stores for trendy consumer goods. Third, Hong Kong society has grown increasingly permissive to upward social mobility from the lower strata, both intra-generational as well as inter-generational. There existed a proliferation of success stories about selfmade and home-grown entrepreneurs, based upon their petty capital derived from accumulated savings-made possible because of their thrift and the inexpensive rental paid for public housing and the cheap wet food supplied by the motherland ${ }^{(22)}$. As demonstrated by a 1985 study by Turner and his associates, the proportion of Hong Kong workers expressing a hope to start a business was substantially higher than found in a comparable study ten years ago ${ }^{(23)}$. There was also a preponderant share of the worker sample, $88 \%$ who articulated an expectation for an upward occupational movement of their posterity vis-à-vis their present position. And almost every worker interviewed was prepared to sponsor their children financially for completing university education or obtaining a professional qualification ${ }^{(24)}$. Fourth, in the labour market and domain of personnel hiring, there had been an evident trend of a decasualisation of the blue-collar labour force ${ }^{(25)}$, an upgrading in skills and productivity (standards) of lower-skilled employees and a lengthening of the work period for which wages were paid, suggesting hence a significant stabilisation in workers' attachment and employment security at enterprises ${ }^{(26)}$. Concomitantly, there had also been a creeping and yet steady narrowing of the income differentials between manual blue-collar workers and whitecollar employees ${ }^{(27)}$.

All these developments-the uplifting in status, aspirations and life-style of the industrial blue-collars-and their growing economic affluence hence serve as a pointer to their convergence with the middle class or "central class". They lend evidence, prima facia, to the thesis of embourgeoisement of the working class, which suggests that the working class has become increasingly assimilated into the middle class and is in an attrition process of withering away and being drained of its traditional class consciousness and solidarity ${ }^{(28)}$.

However, the thesis of embourgeoisement comes under question around the turn of the millennium in the advents of globalisation and successive waves of recession, as the following shows.

\section{Re-emergence of an impover- ished and diversified working class: industrial deprivation and pauperisation in the labour market of a post-indus- trial society?}

Hong Kong's labour force has been haunted by creeping problems of redundancies and unemployment since the beginning of the 1990s. The predicament began because locally based factories moved northwards across the border in large numbers in search for cheaper labour and land in the mainland (as a low-cost "hinterland"). The migration en masse of Hong Kong-based production plants, pushed away due to the spiralling pressures of acute land and labour shortages as well as escalating production costs, led to a dramatic "withering away" of Hong Kong's manufacturing sector. This de-industrialisation process, which began in the mid-1980s, has drastically curtailed the size (in both absolute and relative terms) of Hong Kong's industrial employment-the bastion of the traditional working class. At the same time, Hong Kong rediscovered its commercial role in the 1990s by resuming its modern business and financial centre. In this re-commercialisation process, it attempts to excel in the provision of high value-adding service activities, placing a premium on technology, modern hardware, and human resource quality. As Hong Kong advances and diversifies its core tertiary activities into real estate property development, retail sales, tourism, hotel and catering and associated hospitality trades as well as new areas such as container port handling and trucking, air cargo transport, banking and financial services and telecommunications, a variety of white-collar professional, manage-

20. Ibid..

21. Ibid., p. 137

22. Thus, it had been observed by Turner and his associates: "workers do not think of advancement in collective terms because they are in general ambitious as individuals, and intends to get on personally. Many hope to move up to become independent entrepreneurs themselves...". See Turner et al., The Last Colony: But Whose?, Cambridge, Cambridge University Press, 1980, p. 13.

23. Turner, H. A., Fosh, Patricia and $\mathrm{Ng}$, Sek Hong, op.cit.

24. Ibid., p. 132.

25. De-casualisation in the labour market was evidenced by the secular decline in the number of casually or temporarily hired workers (saan kung or cheung saan kung) and their substitution by workers having the status of permanent employment (cheung kung)

26. Ibid., p. 27.

27. Ibid., pp. 31-32.

28. Goldthorpe, J. H., Lockwood, D., Bechhofer, F. and Platt, J., The Affluent Worker: Industrial Attitudes and Behaviour, Cambridge, Cambridge University Press, 1968. 
rial and service occupations, both new and established, proliferate and expand in size.

The relocation of Hong Kong's manufacturing industry has inevitably made thousands of industrial blue-collar workers redundant. Mostly middle-aged craftsmen and semi-skilled production workers, these affluent workers of yesterday have experienced almost insurmountable difficulties in transferring to other trades. Retraining in new skills was advanced by the government as a logical prescription to assist these workers in their career movement and transfer. However, because of their age constraints many of them were hard-core "unemployable" not amenable to retraining and re-skilling. They were either trapped in the industrial "unemployed army" or forced to move downward but laterally to lower-status peripheral callings in the service sector to work as security guards, dustmen or petrol station attendants.

In retrospect, unemployment and employment have afflicted Hong Kong for more than a decade since the early 1990s, especially when the economy was beset by a succession of cyclical downturns shortly after the inception of the SAR. These problems of unemployment and redundancies which plagued Hong Kong's labour and society were partly due to the vicissitudes of economic adversity in periods of downturn and partly because of, as noted above, the restructuring of the economy, which gave rise to structural imbalances of sectoral employment and skills mix in the labour market glutted by labour surplus in the sunset industries. Looking back, the waves of economic adversity hit Hong Kong three times during the nine years since the SAR was inaugurated when business closures and corporate restructuring (notably, alongside exercises of downsizing and de-layering) to sustain firms' survival and competitiveness were on the upsurge. The first episode emanated from the East Asian financialcum-currency crisis in 1997. The second followed the American-led global recession in the wake of the collapse of the "new economy" (a euphoria about cybetics technology) bubble and the 11 September episode of 2001. The third was caused by the SARS epidemic of 2003. In the advents of these crises, unemployment intensified and escalated. At its peak, unemployment affected and impeded almost every sector of the Hong Kong economy across-the-board. Those who were particularly vulnerable were located not only in the manufacturing production industry but also in the service sector including the distributive trades of wholesale and retail services, catering, building and construction, property agency services, as well as transport and financial servicing. Added to this was a creeping phenomenon that "the effects of corporate downsizing and lay-offs spread to the upper seg- ment of the occupational hierarchy (29)", as evident in visible increases in the unemployment rates for the more elitist groups of managers and administrators, and professionals in the upper echelon. The plight of unemployment was no longer limited to the blue-collar workforce at the grass-roots level. In Marxian language, the unemployed industrial army among the working class was replenished from those hived off from white-collar occupations and service industries, in addition to those production workers displaced earlier from the de-industrialisation syndrome.

Still, working people at the grass-roots levels were most vulnerable and anxious about perils of unemployment, in both the service and production sectors. Against an environment beset by a sustained deflation spiral, the plight of "glut" became conspicuous almost everywhere across a spectrum of industries in causing a vicious cycle for the feeble economy and labour market. The doldrums and pessimistic business prospects caused firms to consolidate their activities and downsize, and even levy pay cuts as a follow-on. The subsequent linkage effects of people's curtailed income and ability to spend and consume, in turn, sustained a persisting recession in the consumption oriented industrieswhich were income sensitive-such as retail, restaurants and catering, leisure industries and even the real estate property sector.

The modern working class in post-industrial Hong Kong emerges again with sharper contours, when their members now become visibly disadvantaged, impoverished and proletarianised. Their resurgence is to a large extent an outgrowth of cyclical recession as well as "globalisation." Globalised competition, alongside its elitist ethos of individualised excellence at the expense of the less able and less competent, has been to polarise and widen the wealth and income gap between those who "have" and those who "have not," between the "able" and "less able." Such a trend of increasingly unequal distribution of income within Hong Kong society is symptomatic, in the consistent upward drift of the Gini coefficient since the 1990s. It ascended, for example, from 0.476 in 1991 to 0.518 in 1996 and further to 0.525 in $2001^{\left({ }^{30}\right)}$ (see tables 2 and 3). Earlier, the dislocation of the mid-career industrial workers displaced from manufacturing production works and the weak labour market position of recent Chinese immi-

29. Economic Analysis Division, Financial Services Bureau, Hong Kong SAR government, 2001 Economic Background, Hong Kong, Government Printing Department, 2002.

30. Census and Statistics Department, Hong Kong SAR Government, Key Statistics of the 2001 Population Census, Hong Kong, Census and Statistics Department, 2001. 
Table 2. Gini coefficient of Hong Kong

$\begin{array}{lllll}1981 & 1986 & 1991 & 1996 \quad 2001\end{array}$

Gini

$\begin{array}{llllll}\text { coefficient } & 0.451 & 0.453 & 0.476 & 0.518 & 0.525\end{array}$

Source: Census and Statistics Department (1992) and (2002).

Table 3. Gini coefficient of selected developed economies

\begin{tabular}{l|c|c}
\hline Places & Gini coefficient & Survey year \\
\hline Hong Kong, China & 0.525 & 2001 \\
\hline Australia & 0.352 & 1994 \\
\hline Canada & 0.331 & 1998 \\
\hline France & 0.327 & 1995 \\
\hline Germany & 0.283 & 2000 \\
\hline Japan & 0.249 & 1993 \\
\hline South Korea & 0.316 & 1998 \\
\hline Singapore & 0.425 & 1998 \\
\hline Sweden & 0.250 & 2000 \\
\hline Taiwan & 0.326 & 2000 \\
\hline United Kingdom & 0.360 & 1999 \\
\hline United States & 0.408 & 2000 \\
\hline
\end{tabular}

Source: The World Bank (2004), Census and Statistics Department (2002) and Distribution of income in Taiwan.

grants from the mainland, alongside a growing army of foreign guest workers, together constituted a potential breeding ground for an urban sub-class of the industrially deprived and economically fragile. Often isolated and solitary, socially marginalised and inarticulate, these workers lack both the consciousness and ability to organise themselves into trade unions for the collective representation of their interests. Their predicament suggests a new industrial proletariat, trapped in the secondary layer of the Hong Kong labour market ${ }^{(31)}$, who are "however, increasingly marginalised" because of "their labour market vulnerability" and the relative ineffectiveness of their own collective organised power in defending their job interests ${ }^{(32)}$.
Later, adding to their ranks and compounding the hybrid composition of this modern working class are those located at the periphery of the labour market because of i) re-casualisation of the labour market; ii) unemployment stemming from the post-1997 waves of recession, and iii) the "sweating" conditions of excessive long hours and depressant low pay in a number of service trades.

A casual labour market has again emerged-largely as a sequel to the popularisation of flexi-hiring practices as a prescription of modern human resource management to advance the adaptability and competitive ability of a firm. Such practices, while helping businesses to save on labour overheads, marginalise and push into "atypical employment" the non-regular labouring people such as the part-timers, temporary hires, those on fixed short term contracts (seasonal workers) as well as those converted into self-unemployed on "outsourcing" arrangements vis-à-vis their former employing organisations ${ }^{(33)}$. Typically, they are low paid and living on meagre incomes and as such, are deprived of any employment and income security, and of the protection of the law (notably, the Employment Ordinance prescribing a statutory floor of employment rights for their regular counterparts hired on a continuous contract). And Hong Kong trade unions typically find organisation in their domain tricky, and the reason is three-fold: the large number of peripheral workers with low awareness about the trade unions; they are widely dispersed and always mobile without any locational stability; and they have little marketable skill and thus little strength in the labour market, which hardly sustains an effective bargaining position vis-à-vis their employers ${ }^{(34)}$.

Industrial docility in the urban subclass of the peripherals has been sustained and accentuated in the SAR because of shifts and further depression in the bulging labour market, now emanating from the epidemic of business closures and corporate downsizing. The ranks of the unemployed industrial army were increasingly replenished from the main-

31. Ng Sek Hong, "Labour and Employment", in Joseph Y. S. Cheng and Sonny S. H. Lo (eds.), From Colony to SAR: Hong Kong's Challenges Ahead, 1995, pp. 197-225.

32. Ibid., pp. 203-4, 220

33. In addition, the enterprise as the principal may externalise and farm out its non-core tasks to subcontracting or outsourcing agencies which in turn are employers of either casual or regular workers?as practised in such areas of "secondary" service work like cleaning, car-park management and security work. This form of casualisation and employment of indirect labour, virtually reminiscent of the factory system in Victorian Britain, has been found conducive to low pay because of the subcontractor's endeavours to squeeze on labour costs in the competitive bidding for the "outsourcing" assignment.

34. The exceptions are probably, however, in the stevedoring and container port trades, where lorry drivers hired off from regular employment and now retained mostly on the basis of a contract for services are known to have organised themselves into solidaristic, effective and powerful labour unions. 
stream divisions of the general labour force. As earlier noted, these affected (and afflicted) employees now include managerial and professional personnel; sales and clerical workers, as well as other white-collar, grey-collar (technicians) and blue-collar workers.

A key feature of the modern working class, however, is the syndrome of low pay and lengthy work hours besetting a diversity of service trades in the lower tier of the occupational structure, especially those associated with atypical employment. As noted above, there has been a creeping phenomenon of "atypical employment," including non-regular hiring under part-time, temporary, and short-term contractual provisions, which has contributed to the low-wage syndrome. To explain, both the recession waves and the pressure of global competition induce Hong Kong enterprises to restructure their business activities and workplace arrangements, in order to cut costs as well as enhance their resource-based competency. These restructuring levers were modelled extensively, as a common austerity drive among enterprises, along Western lines of de-layering, outsourcing, de-establishment and down-sizing.

This syndrome of growing atypical employment helps to explain the low-wage phenomenon in the context of restructuring the Hong Kong labour market and its propensity for regulatory institutions such as minimum-wage regulation. The official statistics published by the Census and Statistics Department suggests an association of this new category of employment status with low wages among employees in Hong Kong. An estimate by the Census and Statistics Department in 1999 put the size of the part-time workforce at 116,000 or $4.1 \%$ of the employed labour force. This number represents a sizeable advance from the earlier statistics of 82,000 part-time workers (or $2.8 \%$ of the general waged labour force) recorded by the government for the fourth quarter of 1997. Part-time working as a common form of atypical employment advanced and expanded rapidly within a short interval as a result.

The fringe nature of these part-time workers as a peripheral segment of the general labour force was evident. As illustrated by the official survey, these part-time labourers were likely to be female and married persons in the middle-age braches. A sizeable proportion of them were also housewives, as hinted at by about one-fifth of the respondents (20.8\%) who cited "attention required for housework" as an explanation for their part-time work status. The largest employer of these marginal labouring groups was the hybrid service sector of "wholesale, retail, and import/export trades, restaurants and hotels" which engaged about $27 \%$ of the whole part-time population. Low wages also appeared: a significant fraction (16.9\%) earned less than $\mathrm{HK} \$ 2,000$ a month, and as high as $71.5 \%$ reported monthly earnings of less than HK $\$ 6,000$ derived from their main employment. Unskilled and skilled marginality were also a common problem among these workers, of whom one-third (33.2\%) were in occupations graded as elementary in skill status, with another one-fiftieth (19.3\%) belonging to the general skill category of service workers and shop assistants ${ }^{(35)}$.

This labour market syndrome of low wages and atypical employment helps to demonstrate again a core phenomenon in Hong Kong's business restructuring exercises. The popularisation of flexibility in employment has prompted the relatively low paying industries, especially service industries, to "casualise" (or re-casualise) their workforce to save on labour costs and associated overheads. Apparently, the part-time work hour norm also appealing to employers concealing low wages as pay becomes fractionalised and denominated on an hourly basis. As earlier reported in the mass media, this syndrome of depressant wage levels has become probably common in some restaurants and fast-food stores because of the persistent glut in labour supply at the low skill levels ${ }^{(36)}$.

Moreover, outsourcing of non-core work activities by corporate employers has helped nurture a "low pay" syndrome. A vicious circle is always perpetuated as competitive bidding for contract tender among subcontractors tends to prompt the latter to hire workers on low pay in order to save on labour costs. Such vicissitudes of outsource subcontracting leading to a "low wage" squeeze are known to be practiced widely in the cleaning trade and among providers of security guard services who are also afflicted by excessive long work hours ${ }^{(37)}$. The depressing working conditions arising from outsourcing arrangements among these service industries have been heavily castigated by organised labour, which has articulated a strong demand for government to introduce a protective minimum wage law to ensure that the pay of these peripheral workers cannot fall below a stipulated statutory floor. It is likely that these peripheral workers will continue to be trapped in this disadvantaged position and industrial deprivation of the modern

35. Census and Statistics Department, Social Data collected via the General Household Survey, Part-time Employment, Special Topics Report $\mathrm{n}^{\circ} 24$, Hong Kong: Printing Department, 1999.

36. Ng Sek Hong and Poon, Carolyn Y. W., Business Restructuring in Hong Kong: Strengths and Limits of Post-Industrial Capitalism, Hong Kong, Oxford University Press, 2004.

37. The Workplace Study Group, The Chinese Management Centre, A Report on the Survey of Employment and Working Conditions of Security Personnel in the Property Management Industry, Hong Kong, The University of Hong Kong, August 2002. 
$\pi$

working class of late urbanism in post-industrial Hong Kong.

The Hong Kong working class and its labour movement did not lack a nostalgic history of its early-day agitation in protest against employers and capital. In retrospect, there are three identifiable waves of an upsurge in the working class movement in Hong Kong. These are: its embryonic yet euphoric heydays during the pre-war era of the 1920s, and later the rehabilitation years following immediately the Second World War; the post-war industrialisation period; and the current post-industrialisation period after the 1990s.

In its earlier stages, noticeably in the period before and after the Second World War, the working class phenomenon was very distinctive of its blue-collar characteristics. This is evidenced by the successful Seamen's Strike of 1922 and the 1925-26 Hong Kong Canton (Guangzhou) General Strike and Boycott which marked the prelude to an era of bitter and prolonged political strife between the Nationalist Party and Chinese Communist Party that was to dictate the course of contemporary Chinese politico-labour history ${ }^{(38)}$. After experiencing a post-war period of fairly intensive industrial haggling and strife in the late 1940s and early 1950s, Hong Kong entered a period of relative industrial peace and stability which coincided with its process of economic take-off and industrialisation ${ }^{(39)}$. Although lacking a strong vestige of class tradition, Hong Kong had an enormous oversupply of industrial production (or blue collar) workers. Objectively speaking, these production workers engaged in the industrial secondary sector were potential members of the territory's working class, given the widespread vicissitudes of their industrial drudgery, economic pauperisation and terrible working and employment conditions, and thus the deprived quality of working life as vividly documented by England and Rear ${ }^{(40)}$. However, whatever mutual feelings of working class alienation, deprivation and anti-capital consciousness they might have shared as "refractory" labour were swamped by their effacing and lukewarm orientation towards workplace collectivism and concerted articulation of industrial agitation and militancy. Instead, what prevailed was a scarcity of employment opportunities, an anxiety for trouble aversion and a preference for industrial docility-all purportedly bred of their "refugee" character and mentality.

In its current third wave of gestation, the working class also looks docile and incapable of articulating a strong class identity and interest. We would argue that the diversity of its composition as a hybrid mix of low-skill service workers and the fluidity of the nature of employment have not been con- ducive to the nurturing and consolidation of a new working class consciousness and solidarity among their ranks. In particular, workers labouring in diverse categories of atypical employment have not been amenable to organisation by trade unions because of the transient nature of their employment and hence the inherent lack of stable attachment to the workplace. Even the role of the trade unions in representing and articulating the occupational interest of these working people at the grass-roots level has been limited, and lacking any signs of militancy as a refractory labouring mass. The labour movement's vociferous lobby on the SAR government to enact a minimum wage law and to regulate standard work hours for protecting marginal workers has so far been perfunctory as the legislative motions are still in an "impasse". The SAR government, adhering to its doctrinal faith in a "free" labour and wage market as a Hong Kong ethos and anxious not to antagonise business and capital, averted the painstaking policy decision of introducing legislation to prescribe a minimum wage level and govern work hours for the working population. Instead, it devolved a power of selfregulation to both sides of industry within the low pay sector. The government launched an essentially voluntaristic ex-

38. Chesneaux, Jean, The Chinese Labor Movement 1919-1927, Stanford: Stanford University Press, 1968, pp. 312-18, 332-34; also Wales, Nyum, The Chinese Labor Movement Freeport: Books for Libraries Press, 1945.

39. This post-war industrialisation process was Hong Kong's first experience of economic restructuring, made possible by the massive inflow of refugee Chinese capital alongside the industrial know-how and technical manpower and an influx of cheap unskilled /semi-skilled labour brought to Hong Kong by people seeking asylum after the liberation of the mainland in 1949. The swift conversion of the territory into an industrial economy was also partly caused by its "de-commercialisation" Hong Kong's traditional mix of commercial and mercantile activities began to recede as China entered a period of political turmoil because of the civil war. This de-commercialisation process was further accelerated by the trade embargo levied upon China by the United Nations during the 1950 s in the aftermath of the Korean War. Trade sanctions almost halted the previously huge flow of goods between the mainland and the rest of the world that was handled through Hong Kong's port. See Cheung, Grace H. Y. Ho, Elaine Y. Y., Ng, Sek Hong and Poon, Carolyn Y. W., "Business Restructuring in Hong Kong", in David G. Lethbridge and $\mathrm{Ng}$ Sek Hong (eds.), The Business Environment in Hong Kong, 4th edition, Hong Kong, Oxford University Press, 2000, pp. 154-84.

40. Hong Kong workers in the late 1960s and early 1970s were labouring for low wages yet with long working hours. They performed the longest working day and the longest working week vis-à-vis their counterparts in other South-East Asian cities. A survey of resettlement estate (public housing estate) residents carried out by the Sociology Department of the University of Hong Kong revealed that the majority of the heads of households had to work all Saturdays and Sundays. "Only 12 per cent worked 8 hours or less per day and 42 percent worked 11 hours or more each day". See Hopkins, Keith, "Housing the Poor", in Keith Hopkins (ed.), Hong Kong: The Industrial Colony, Hong Kong, Oxford University Press, 1971. The average income they earned was a meagre amount of HK\$332 (about £22) a month. In a study of shop workers Chaney in 1969, half of the subjects were found to work 12 hours or more a day and over $80 \%$ worked seven days a week. "It appeared that the majority of shopworkers spent practically all their waking hours at work". See Chaney, D. C., "Levels of Emotional Strain in South-East Asian Cities", unpublished manuscript, Chinese University of Hong Kong, 1971. England and Rear described the vicissitudes of such inhospitable working conditions as "sweat labour". See England, Joe and Rear, John, Chinese Labour under British Rule, Hong Kong, Oxford University Press, 1975. 
ercise, a "Wage Protection Movement" for employees in the two industries notorious for low wages-the cleaning and security services sector. And the administration is equally lukewarm about enhancing the Employment Ordinance in order to bestow upon the part-time employees and other workers engaged in atypical employment a statutory floor of employment rights analogous to those now available for their fulltime counterparts.

The working class, incapable of self organisation and of mobilising a collectivistic movement to campaign for better- ment, has been looking to the government for leverage to lift its deprived members from the "doldrums" they are in. However, these prospects are not sufficient to prompt optimism since the SAR government, anxious to perform its agency role to work for Hong Kong's prosperity and stability, continues to rope dance between capital in business and the industrially peripheral among the working class. $\bullet$ 